\title{
BIN1 wt Allele
}

National Cancer Institute

\section{Source}

National Cancer Institute. BIN1 wt Allele. NCI Thesaurus. Code C52372.

Human BIN1 wild-type allele is located in the vicinity of 2q14 and is approximately $60 \mathrm{~kb}$ in length. This allele, which encodes Myc box-dependent-interacting protein 1, may be involved in the regulation of both synaptic vesicle endocytosis and cellular differentiation. 